\title{
FAKTOR RISIKO KEJADIAN BERAT BADAN LAHIR RENDAH DI AREA PERTANIAN (STUDI DI KABUPATEN BREBES)
}

\author{
(Risk factors for low birth weight in the agricultural area (study in Brebes district))
}

\author{
Diah Ratnasari ${ }^{*}$, Suhartono ${ }^{2}$, Mohammad Zen Rahfiludin ${ }^{3}$ \\ ${ }^{1}$ Departemen Ilmu Gizi, Fakultas Kedokteran, Universitas Diponegoro, Semarang 50275 \\ ${ }^{2}$ Departemen Magister Kesehatan Lingkungan, Universitas Diponegoro, Semarang 50275 \\ ${ }^{3}$ Departemen Gizi Kesehatan Masyarakat, Universitas Diponegoro, Semarang 50275
}

\begin{abstract}
The aim of this study was to analyze the risk factors of Low Birth Weight (LBW) in agricultural area (Breses district) with high pesticide exposure. The research was an observational study with case control design. Study subject were post partum-productive age (20-35 years) women, consisting of 60 cases (LBW) and 60 controls (non-LBW). The independent variables were maternal weight gain during pregnancy, MUAC in early pregnancy, hemoglobin levels in the third trimester body mass index before pregancy and level of pesticides exposure. Nutrient intake data was obtained by semiquantitative food frequency questionnaires (FFQ), maternal and child health (KIA) book and data on level of pesticide exposure was obtained through a structured interview. Data were analyzed by calculating the Odds Ratio (OR) using logistic regression. There was no differences in age between cases and controls. Median length, mother's education level, BMI and MUAC among the cases was lower than the control group. Low protein adequacylevel $(O R=8.9 ; 95 \% C I: 1.6-227.7)$; less weight gain $(O R=9.1 ; 95 \% C I: 2.9-28$,$) ; High pesticides$ exposure (OR=7.4; 95\%CI:1.3-40.9); low MUAC <23.5 cm (OR=4.6; 95\%CI:1.3-15.5) were LBW risk factors in Brebes. Inadequacy of nutritients and high pesticides exposure during pregnancy was $L B W$ risk factors. Women are advised to increase nutrients intake and avoid pesticides exposure during pregnant.
\end{abstract}

Keywords: low birth weight, risk factors, pesticides exposure

\begin{abstract}
ABSTRAK
Penelitian ini bertujuan menganalisis faktor risiko kejadian Berat Badan Lahir Rendah (BBLR) di area pertanian (Kabupaten Breses) dengan paparan pestisida yang tinggi. Penelitian ini merupakan penelitian observasional dengan desain case control. Subjek penelitian adalah ibu post partum berumur produktif (20-35 tahun), terdiri atas 60 kasus (BBLR) dan 60 kontrol (tidak BBLR). Variabel bebas yang diteliti adalah kenaikan berat badan ibu selama hamil, lingkar lengan atas (LiLA) pada awal kehamilan, kadar hemoglobin $(\mathrm{Hb})$ trimester tiga, Indeks massa tubuh (IMT) sebelum hamil dan tingkat paparan pestisida. Data asupan zat gizi diperoleh dengan metode food frequency questionnaires (FFQ) semikuantitatif dan buku kesehatan ibu dan anak (KIA) subjek. Data tingkat paparan pestisida diperoleh melalui wawancara terstruktur. Data dianalisis dengan menghitung Odds Ratio (OR) menggunakan regresi logistik. Tidak terdapat perbedaan umur antara kelompok kasus dan kontrol. Median lama pendidikan, IMT dan LiLA ibu kelompok kasus lebih rendah dibandingkan kelompok kontrol. Tingkat kecukupan protein yang kurang (OR=18,9; 95\%CI:1,6-227,7); kenaikan berat badan kurang $(\mathrm{OR}=9,1 ; 95 \% \mathrm{CI}: 2,9-28)$; tingkat paparan pestisida yang tinggi $(\mathrm{OR}=7,4 ; 95 \% \mathrm{CI}: 1,3-40,9)$; LiLA $<23,5 \mathrm{~cm}(\mathrm{OR}=4,6$; 95\% CI:1,3-15,5) merupakan faktor risiko BBLR di Kabupaten Brebes. Ketidakcukupan gizi dan paparan pestisida yang tinggi selama kehamilan merupakan faktor risiko BBLR. Ibu hamil disarankan untuk meningkatkan asupan gizi dan menghindari paparan pestisida.
\end{abstract}

Kata kunci: BBLR, faktor risiko, paparan pestisida

\section{PENDAHULUAN}

Jumlah angka kematian bayi di Indonesia masih tinggi dibandingkan negara ASEAN lainnya. Indonesia menduduki peringkat ke-4 tertinggi setelah Kamboja, Myanmar, dan Laos (Depkes RI 2009). Menurut data Survei Demografi Kese- hatan Indonesia (SDKI), terdapat kasus angka kematian bayi sebesar 34 per 1.000 kelahiran hidup dan angka kematian neonatal sebesar 19 per 1.000 kelahiran hidup pada tahun 2007 (SDKI 2012). Angka kematian bayi yang dilaporkan oleh puskesmas Kab. Brebes tahun 2014 sebesar 10,4 per 1.000 kelahiran hidup atau sebanyak 348

\footnotetext{
"Korespondensi: Telp: +6285600621409, Surel: diahratna1708@gmail.com
} 
kasus kematian bayi dari 33.456 kelahiran hidup (Dinkes Kab. Brebes 2014). Faktor penyebab kematian bayi diantaranya tingkat status gizi ibu hamil, tingkat keberhasilan program Kesehatan Ibu dan Anak (KIA) dan Keluarga Berencana (KB) serta kondisi lingkungan, sosial ekonomi dan BBLR (Dinkes Kab. Brebes 2014).

BBLR di Indonesia tahun 2014 masih cukup tinggi yaitu (10,2\%), lebih rendah dari tahun 2010 $(11,1 \%)$ (Riskesdas 2013). Jumlah kasus BBLR di Jawa Tengah tahun 2013 sebanyak 21.573 (3,75\%). Hal ini meningkat dibanding tahun 2012 sebanyak 21.184 (3,73\%) (Dinkes Jateng 2013). Sebanyak 29 Kabupaten/Kota sudah mencapai target $100 \%$, hanya 6 Kabupaten yang masih di bawah target yaitu Banjarnegara (93,69\%), Kebumen $(43,13 \%)$, Purworejo $(99,58 \%)$, Wonosobo $(84,62 \%)$, Blora $(99,42 \%)$ dan Brebes $(35,02 \%)$ (Dinkes Jateng 2013). Brebes merupakan Kabupaten di Jawa Tengah yang tingkat pemakaian pestisidanya cukup tinggi karena luasnya lahan pertanian khususnya bawang merah. Keterlibatan ibu hamil dalam kegiatan pertanian menyebabkan mereka terpajan pestisida ketika petani melakukan penyemprotan di sawah dan pada saat yang bersamaan, para ibu hamil sedang mencari hama atau mencabut rumput.

Penelitian sebelumnya menunjukkan sejumlah besar faktor yang telah ditemukan yang berkaitan dengan kejadian BBLR adalah faktor biologi seperti umur kehamilan, tinggi dan berat badan ibu, faktor gaya hidup (kebiasaan diet, konsumsi kafein, alkohol, dan tembakau) (Torrance et al. 2007), karakteristik lingkungan, komplikasi medis saat kehamilan, prematuritas, perilaku ibu yang buruk, antropometri ibu, karakteristik demografi, sosial ekonomi, pendidikan ibu, dan penghasilan rumah tangga. Status gizi Ibu sebelum hamil dapat ditentukan dengan indikator berat badan, tinggi badan, Indeks Massa Tubuh (IMT), dan Lingkar Lengan Atas (LiLA). Status gizi yang baik pada ibu sebelum hamil menggambarkan ketersediaan cadangan zat gizi dalam tubuh ibu yang siap untuk mendukung pertumbuhan janin pada awal kehamilan (Nahar 2007; Rosha et al. 2012). Hasil penelitian di Kabupaten Magelang menunjukkan adanya hubungan yang signifikan antara paparan pestisida dengan kejadin BBLR (Setyobudi et al. 2013) serta penelitian yang dilakukan di Soppeng menunjukkan adanya pengaruh faktor maternal terhadap kejadian BBLR (Rahmawati \& Nur 2010).

Keracunan kronis akibat pestisida dapat bersifat karsinogenic (pembentukan jaringan kanker pada tubuh) dan mutagenic (kelahiran anak cacat dari ibu yang keracunan) (Cahaya $e t$ al. 2007). Studi oleh EWG (The Environmental Working Group) menemukan bahwa bayi baru lahir rata-rata mengandung racun, merkuri, fire retardant, dan pestisida (Fusani et al. 2007). Masuknya pestisida dapat melalui kulit, mulut dan pernafasan. Gangguan dalam mekanisme pengaturan ini dapat menyebabkan terjadinya disfungsi tiroid, yaitu hipotiroid dan hipertiroid. Hipotiroid merupakan keadaan dimana kelenjar tiroid tidak menghasilkan cukup banyak hormon tiroid. Kurangnya asupan hormon tiroid dalam tubuh wanita hamil akan turut mengganggu proses tumbuh kembang janin, padahal di usia dini hormon tiroid sangat bermanfaat meningkatkan pertumbuhan dan perkembangan kecerdasan, jika hipotiroid dibiarkan dalam jangka panjang maka bukan tidak mungkin janin yang dilahirkan akan menjadi generasi yang lambat dalam merespons, mengalami keterbelakangan mental, BBLR, bahkan cacat fisik (Noni et al. 2013).

Kabupaten Brebes merupakan salah satu daerah penghasil bawang merah tertinggi di Indonesia dengan penggunaan pestisida yang tinggi. Sektor pertanian merupakan penopang perekonomian masyarakat kabupaten Brebes dengan komoditi utamanya bawang merah. Menghadapi serangan organisme pengganggu tanaman (OPT), masyarakat menggunakan pestisida untuk mengatasinya karena menurut mereka hasilnya efisien, mudah dan efektif. Penggunaan pestisida cenderung tinggi yakni bisa dilakukan penyemprotan hingga tiga hari sekali selama proses penanaman sampai dengan proses pemanenan karena umumnya petani mengantisipasi OPT sejak awal tanam. Keberadaan OPT di lahan akan mendorong petani menggunakan pestisida secara berlebihan dengan meningkatkan takaran, frekuensi penyemprotan dan komposisi jenis campuran pestisida yang digunakan. Bahkan tidak sedikit petani menganut cover blanket system dimana ada ataupun tidak ada OPT, pestisida tetap diaplikasikan.

Paparan pestisida yang tinggi berkontribusi menyebabkan BBLR, tetapi penelitian mengenai konstribusi paparan pestisida terhadap kejadian BBLR di Kabupaten Brebes belum dilakukan sehingga belum diketahui secara pasti. Penelitian ini bertujuan menganalisis faktor risiko kejadian BBLR di area pertanian dengan paparan pestisida yang tinggi. Diharapkan hasil penelitian ini dapat memberi informasi dan menambah pengetahuan bagi dinas kesehatan dalam melakukan intervensi khususnya dalam mencegah terjadinya bayi dengan BBLR. 


\section{METODE}

\section{Desain, tempat, dan waktu}

Desain penelitian adalah observasional dengan rancangan case control. Penelitian dilakukan di wilayah Kabupaten Brebes, Jawa Tengah dengan lokasi penelitian di Puskesmas Brebes, Puskesmas Kaligangsa, dan Puskemas Pemaron. Penelitian dilakukan pada tanggal 24 Oktober-17 November 2016 (enam minggu).

\section{Jumlah dan cara pengambilan subjek}

Populasi dalam penelitian ini adalah seluruh ibu yang mempunyai bayi usia 0-6 bulan yang memeriksakan diri dan tercatat secara lengkap di buku register bidan praktek di wilayah kerja Puskesmas Brebes tahun 2015. Subjek penelitian adalah ibu yang mempunyai bayi usia $0-6$ bulan yang didiagnosis BBLR atau tidak didiagnosis BBLR di Kecamatan Brebes.

Pengambilan subjek dilakukan secara purposive sampling yaitu dengan memilih Kecamatan Brebes (3 puskesmas) di wilayah Kabupaten Brebes dengan alasan Kecamatan tersebut padat penduduk dan memiliki jumlah BBLR yang tertinggi. Kemudian dari Puskesmas diperoleh data jumlah BBLR tiap Desa. Data ibu dengan atau tanpa BBLR diperoleh berdasarkan catatan PKD tiap Desa. Terdapat 60 subjek pada masing-masing kelompok yang terdiri dari 60 kasus (BBLR) dan 60 kontrol (tidak BBLR), maka jumlah subjek dalam penelitian ini adalah 120 subjek. Kriteria inklusi dalam penelitian ini yaitu ibu yang mempunyai bayi usia 0-6 bulan yang didiagnosis BBLR yang berada di Kabupaten Brebes, ibu berusia produktif (20-35 tahun), ibu mempunyai data lengkap yang terdiri dari identitas subjek dan buku KIA, bersedia menjadi subjek penelitian dengan menandatangani informed consent. Kriteria eksklusi pada penelitian ini yaitu Ibu sakit atau terkena komplikasi selama kehamilan seperti terkena penyakit gestasional diabetes dan preeklamsia, serta ibu yang tidak kooperatif.

\section{Jenis dan cara pengumpulan data}

Pengumpulan data asupan gizi serta tingkat kecukupan protein, dan tingkat kecukupan energi diperoleh melalui wawancara langsung menggunakan food frequency questionnaire (FFQ) semikuantitatif. Jumlah asupan zat gizi dihitung menggunakan program Nutrisurvey 2007. Asupan zat gizi kemudian dibandingkan dengan angka kecukupan gizi (AKG) yang dianjurkan (Hardinsyah 2004).

AKG individu yang diperoleh merupakan AKG individu sebelum hamil. Karena tingkat ke- cukupan gizi yang diperlukan pada penelitian ini adalah tingkat kecukupan gizi selama kehamilan maka kebutuhan energi ditambahkan $300 \mathrm{kkal}$, protein 20 gram. Data karakteristik subjek (umur, IMT dan lama pendidikan) diperoleh melalui wawancara langsung dengan subjek. Paparan pestisida dalam lingkungan ibu hamil ketika ibu ikut dalam kegiatan pertanian diperoleh dari hasil wawancara dan observasi yang dikategorikan menjadi terpapar rendah, bila total skor 1-11 dan terpapar tinngi, bila total skor 12-22. Skor didapatkan dari 11 pertanyaan dengan total skor 22, setelah dinilai berdasarkan skor pada kuesioner. Salah satu contoh dari pertanyaan adalah pada saat pemeliharaan bawang merah, apakah ibu ikut serta dalam penanaman? Jika tidak, skor $=$ 0 dan jika Ya, skor $=1$. Paparan pestisida pada ibu hamil menggunakan proxy indicator pemeliharaan bawang merah berdasarkan asumsi bahwa seluruh perkebunan bawang merah di lokasi penelitian menggunakan pestisida.

\section{Pengolahan dan analisis data}

Analisis univariat dalam penelitian ini meliputi hasil dengan menggunakan tabel distribusi frekuensi, rerata, standar deviasi, nilai maksimum dan minimum. Analisis bivariat dilakukan terhadap dua variabel (variabel bebas dan variabel terikat) yang diduga berhubungan. Pada penelitian ini data yang dihasilkan dikelompokkan sehingga menghasilkan data kategorik. Pada analisis bivariat, data dianalisis dengan menggunakan uji Chi-square. Pada tabulasi silang $2 \times 2$ akan dicari OR untuk mengetahui ada atau tidaknya hubungan antara variabel bebas dengan variabel terikat. Apabila OR $>1$ maka variabel paparan merupakan faktor risiko dan apabila OR $<1$ maka variabel paparan merupakan faktor protektif. Selain itu untuk mengetahui kemaknaan hubungan antara variabel bebas dengan variabel terikat maka uji statistik yang digunakan adalah Chi-square dengan derajat kepercayaan $95 \%(\alpha=$ $5 \%$ ). Bila $p$-value $<0,05$ maka uji statistik bermakna (signifikan) dan bila $p$-value $>0,05$ maka perhitungan statistiknya tidak bermakna.

Analisis multivariat dalam penelitian ini menggunakan uji regresi logistik. Variabel yang masuk dalam analisis multivariat merupakan variabel yang hasil analisis bivariatnya mempunyai $p$-value $\leq 0,25$.

\section{HASIL DAN PEMBAHASAN}

\section{Karakterisktik subjek penelitian}

Penelitian dilakukan pada 120 ibu yang memiliki bayi usia 0-6 bulan, sebanyak $60 \mathrm{ibu}$ 
yang memiliki bayi dengan berat badan lahir < $2.500 \mathrm{~g}$ dipilih sebagai kelompok kasus dan sebanyak $60 \mathrm{ibu}$ yang memiliki bayi dengan berat badan lahir $\geq 2.500$ g sebagai kelompok kontrol.

Tabel 1 menunjukkan karakteristik subjek (umur, pendidikan, IMT, LiLA). Tidak terdapat perbedaan umur $(\mathrm{p}>0,05)$ antara kelompok kasus dan kelompok kontrol. Terdapat perbedaan lama pendidikan, IMT, dan LiLA $(\mathrm{p}<0,05)$ antara kelompok kasus dan kelompok kontrol. Lama pendidikan, IMT, dan LiLA pada kelompok kasus lebih rendah dibandingkan kelompok kontrol.

Tabel 1. Sebaran subjek berdsarkan karakteristik

\begin{tabular}{|c|c|c|c|}
\hline & Kasus & Kontrol & \\
\hline Jenis & $\begin{array}{c}\text { Median } \\
\text { (Min-Maks) }\end{array}$ & $\begin{array}{c}\text { Median } \\
\text { (Min-Maks) }\end{array}$ & $\mathrm{p}$ \\
\hline Umur (thn) & $\begin{array}{c}29,5 \\
(20-35)\end{array}$ & $\begin{array}{c}26,5 \\
(20-35)\end{array}$ & $0,161^{\mathrm{b}}$ \\
\hline $\begin{array}{l}\text { Pendidikan } \\
\text { (thn) }\end{array}$ & $\begin{array}{c}9 \\
(6-16)\end{array}$ & $\begin{array}{c}9 \\
(6-12)\end{array}$ & $0,003^{\mathrm{b}}$ \\
\hline IMT $\left(\mathrm{kg} / \mathrm{m}^{2}\right)$ & $\begin{array}{c}21 \\
(16,6-32)\end{array}$ & $\begin{array}{c}23,9 \\
(16,8-28,8)\end{array}$ & $0,003^{\mathrm{a}}$ \\
\hline $\operatorname{LiLA}(\mathrm{cm})$ & $\begin{array}{c}23,7 \\
(22-34) \\
\end{array}$ & $\begin{array}{c}25,5 \\
(20-32,5)\end{array}$ & $0,002^{\mathrm{b}}$ \\
\hline
\end{tabular}

${ }^{a}$ Independent T-test $;{ }^{b}$ Mann-Whitney test.

\section{Faktor risiko terhadap BBLR}

Faktor risiko BBLR yang dianalisis antara lain tingkat kecukupan energi dan protein, IMT, tingkat paparan pestisida, kenaikan berat badan selama hamil, dan LiLA. Hasil analisis faktor risiko BBLR dapat dilihat pada Tabel 2. Hasil uji Chi-square menunjukkan bahwa tingkat kecukupan energi dan protein rendah, IMT ibu $<18,5 \mathrm{~cm}$ sebelum hamil, tingkat paparan pestisida yang tinggi, LiLA ibu $<23,5 \mathrm{~cm}$, dan kenaikan berat badan ibu selama hamil yang kurang. Hal tersebut merupakan faktor risiko terjadinya BBLR.

Keterlibatan ibu hamil dalam kegiatan pertanian menyebabkan mereka terpajan pestisida misalnya ketika petani menyemprot di sawah dan ibu hamil sedang mencari hama atau mencabut rumput dari tanaman, ketika ibu hamil mencuci pakaian yang dipakai sewaktu bertani memungkinkan ibu terpajan pestisida yang menempel pada pakaian tersebut, demikian halnya pada waktu panen melepaskan bawang dari tangkainya ibu hamil akan terpapar dengan pestisida yang menempel pada kulit bawang yang dipanen. Hal ini dapat menyebabkan terakumulasinya pajanan pestisida dalam tubuh ibu hamil sehingga mengganggu pertumbuhan dan perkembangan janin dalam kandungannya dan dapat mengakibatkan terjadinya BBLR.

Gangguan dalam mekanisme dapat menyebabkan terjadinya disfungsi tiroid, yaitu hipotiroid dan hipertiroid. Gangguan tiroid pada ibu hamil bisa karena kekurangan atau kelebihan hormon tiroid, namun yang paling umum adalah kekurangan hormon tiroid atau hipotiroid. Kurangnya asupan hormon tiroid dalam tubuh wanita hamil akan turut mengganggu proses tumbuh kembang janin, padahal di usia dini hormon ini sangat bermanfaat meningkatkan pertumbuhan dan perkembangan kecerdasan. Jika hipotiroid dibiarkan dalam jangka panjang, maka bukan tidak mungkin janin yang dilahirkan akan menjadi generasi yang lambat dalam merespons, mengalami keterbelakangan mental, berat badan lahir rendah, bahkan cacat fisik (Sari et al. 2013).

Hasil penelitian ini sejalan dengan penelitian yang dilakukan pada tahun 2013 di Kecamatan Ngablak Kabupaten Magelang, ditemukan bahwa paparan pestisida selama kehamilan dapat meningkatkan risiko BBLR. Ibu yang bekerja berkaitan dengan pestisida selama kehamilan berisiko 7,549 kali (IK 95\%:1,388-41,069) untuk melahirkan bayi BBLR (Noni et al. 2013),

Tabel 2 menunjukkan bahwa proporsi ibu hamil dengan tingkat kecukupan energi (TKE) kurang, lebih besar pada kelompok kasus $(71,7 \%)$ dari pada kelompok kontrol $(40,0 \%)$. Hasil uji Chi-square menunjukkan bahwa ada hubungan $(\mathrm{p}<0,05)$ antara TKE dengan kejadian BBLR. TKE yang kurang merupakan faktor risiko kejadian BBLR dapat dilihat dari nilai OR yaitu 3,8 dengan IK 95\%: 1,8-8,1 artinya subjek yang TKE-nya kurang memiliki risiko terkena BBLR 3,8 kali lebih besar dibanding subjek dengan TKE baik.

Kecukupan zat gizi merupakan nilai yang menggambarkan kecukupan zat gizi terhadap pemenuhan zat gizi pada ibu selama masa kehamilan. Pola makan sehari-hari dari ibu hamil dipengaruhi juga dengan adanya faktor budaya yaitu adanya kepercayaan memantang makanan tertentu untuk dikonsumsi dengan alasan apabila dikonsumsi pada saat hamil akan mengakibatkan kecacatan pada bayi yang dilahirkan sehingga asupan makanan pada ibu hamil menjadi kurang (Paath 2004).

Hasil penelitian ini sejalan dengan penelitian yang dilakukan di Kecamtan Bandung di Tulungangung. Hasil uji statistik dalam penelitian ini diperoleh nilai $\mathrm{p}=0,009$, dengan nilai OR 3,161, artinya ibu hamil yang memiliki TKE yang kurang, memiliki risiko tiga kali lebih besar untuk melahirkan bayi dengan berat lahir kurang dari $2.500 \mathrm{~g}$ (Kusuma et al. 2015). Hasil penelitian ini juga didukung oleh penelitian yang dilakukan di Kota Mamuju Sulawesi Barat, bahwa 33 ibu hamil yang memiliki pola makan

J. Gizi Pangan, Volume 12, Nomor 1, Maret 2017 
Tabel 2. Analisis faktor risiko BBLR

\begin{tabular}{|c|c|c|c|c|}
\hline \multirow{2}{*}{ Faktor risiko } & \multicolumn{2}{|c|}{ Status BBLR } & \multirow{2}{*}{$\mathrm{p}$} & \multirow{2}{*}{ OR } \\
\hline & Kasus n(\%) & Kontrol $\mathrm{n}(\%)$ & & \\
\hline \multicolumn{5}{|l|}{ Tingkat kecukupan energi : } \\
\hline Kurang & $32(53,3)$ & $19(31,7)$ & \multirow{2}{*}{0,027} & \multirow{2}{*}{$2,7(1,2-5,2)$} \\
\hline Baik & $28(46,7)$ & $41(68,3)$ & & \\
\hline \multicolumn{5}{|l|}{ Tingkat kecukupan protein : } \\
\hline Kurang & $13(21,7)$ & $1(1,7)$ & \multirow{2}{*}{0,002} & \multirow{2}{*}{$16,3(2-129,3)$} \\
\hline Baik & $47(78,3)$ & $59(98,3)$ & & \\
\hline \multicolumn{5}{|l|}{ Indeks massa tubuh $\left(\mathrm{kg} / \mathrm{m}^{2}\right)$ : } \\
\hline$<18,5$ & $12(80,0)$ & $3(20,0)$ & \multirow{2}{*}{0,013} & \multirow{2}{*}{$4,7(1,2-17,8)$} \\
\hline \multicolumn{3}{|l|}{ Skor tingkat paparan pestisida: } & & \\
\hline Terpapar tinggi $>12-22$ & $15(25,0)$ & $3(5,0)$ & \multirow[b]{2}{*}{0,005} & \multirow[b]{2}{*}{$6,3(1,7-23,2)$} \\
\hline Terpapar rendah $<1-11$ & $45(75,0)$ & $57(95,0)$ & & \\
\hline \multicolumn{5}{|c|}{ Kenaikan berat badan selama kehamilan: } \\
\hline Kurang & $50(83,3)$ & $23(38,3)$ & \multirow{2}{*}{0,001} & \multirow{2}{*}{$8,0(3,4-18,9)$} \\
\hline Cukup & $10(16,7)$ & $37(61,7)$ & & \\
\hline \multicolumn{5}{|l|}{ LiLA } \\
\hline Berisiko KEK $(<23,5 \mathrm{~cm})$ & $30(50,0)$ & $9(15,0)$ & \multirow{2}{*}{0,001} & \multirow{2}{*}{$5,7(2,4-13,5)$} \\
\hline Tidak berisiko KEK ( $\geq 23,5 \mathrm{~cm})$ & $30(50,0)$ & $51(85,0)$ & & \\
\hline
\end{tabular}

yang konsumsi energinya tidak tercukupi, terdapat 16 orang $(48,5 \%)$ yang menderita kurang energi kronis (KEK) dan melahirkan bayi yang berat lahirnya 2500 gram (Rahmaniar et al. 2011) dan penelitian yang dilakukan di wilayah kerja Puskesmas Suruh yang menunjukkan bahwa TKE berhubungan dengan BBLR (Rukmana \& Kartasurya 2014).

Kehamilan menyebabkan meningkatnya metabolisme energi, karena itu kebutuhan energi dan zat gizi lainnya meningkat selama kehamilan. Peningkatan energi dan zat gizi tersebut diperlukan untuk partumbuhan dan perkembangan janin, pertambahan besar organ kandungan, dan perubahan komposisi tubuh, sehingga kekurangan zat gizi yang diperlukan saat hamil dapat menyebabkan janin tumbuh tidak sempurna (Sigalingging 2009). Tambahan makanan untuk ibu hamil dapat diberikan dengan cara meningkatkan baik kualitas maupun kuantitas makanan ibu sehari-hari, bisa juga dengan memberikan tambahan formula khusus ibu hamil atau menyusui (Muwakidah \& Zulaekah 2004).

Tabel 2 menunjukkan proporsi ibu hamil dengan tingkat kecukupan protein (TKP) kurang, lebih besar pada kelompok kasus (53,3\%) dibandingkan kelompok kontrol (11,7\%). Hasil uji Chisquare menunjukkan bahwa terdapat hubungan $(\mathrm{p}<0,05)$ antara TKP dengan kejadian BBLR. TKP yang kurang merupakan faktor risiko kejadian BBLR dapat dilihat dari nilai OR yaitu 8,6 dengan IK 95\%: 3,4-22,1. Artinya subjek yang TKP-nya kurang memiliki risiko terkena BBLR 8,6 kali lebih besar dibandingkan dengan subjek yang tingkat kecukupan proteinya baik.
Protein berfungsi untuk pertumbuhan dan perkembangan janin. Tambahan protein untuk ibu hamil adalah $0,75 \mathrm{gram} / \mathrm{kg}$ berat badan dari jumlah kebutuhan tersebut, sekitar $70 \%$ dipakai untuk kebutuhan dalam janin dalam kandungan. Protein dibutuhkan untuk membentuk plasenta, menambah jaringan tubuh ibu (seperti rahim dan payudara), dan menambah unsur-unsur cairan darah terutama hemoglobin dan plasma darah (Moore 2006).

Jumlah kecukupan protein berpengaruh dalam memprediksi kekurangan energi kronis (KEK) pada masa kehamilan. Jika TKP pada ibu hamil terpenuhi maka kebutuhan protein untuk janin pun tercukupi (Manuaba et al. 2007). Hasil penelitian ini sejalan dengan penelitian yang dilakukan di Kecamatan Bandung, Kabupaten Tulungangung dengan hasil uji statistik dalam penelitian ini diperoleh nilai $\mathrm{p}=0,004$, OR 3,4 dengan nilai IK 95\%: 1,4-7,8 artinya ibu hamil dengan TKP yang rendah berisiko tiga kali lebih besar untuk melahirkan bayi dengan berat lahir yang rendah (Sentha et al. 2015). Selain itu sejalan dengan penelitian yang dilakukan pada ibu vegetarian di Jakarta yang menunjukkan adanya hubungan antara TKP dengan berat badan lahir bayi (Fikawati et al. 2012).

Tabel 2 menunjukkan bahwa proporsi ibu hamil dengan IMT $<18,5 \mathrm{~kg} / \mathrm{m}^{2}$ pada kelompok kasus 33,3\% lebih rendah daripada kelompok kontrol 58,3\%. Hasil uji Chi-square menunjukkan bahwa ada hubungan $(\mathrm{p}<0,05)$ antara IMT dengan kejadian BBLR. IMT $<18,5 \mathrm{~kg} / \mathrm{m}^{2}$ merupakan faktor risiko kejadian BBLR dapat dilihat dari nilai OR yaitu 2,8 dengan IK 95\%: 1,3-5,9 artinya 
subjek dengan IMT $<18,5 \mathrm{~kg} / \mathrm{m}^{2}$ memiliki risiko terkena BBLR 2,8 kali lebih besar diban-dingkan dengan IMT $>18,5 \mathrm{~kg} / \mathrm{m}^{2}$.

Status gizi kurang menunjukkan bahwa ibu sudah mengalami keadaan kurang gizi dalam jangka waktu cukup lama, maka kebutuhan gizi untuk proses tumbuh kembang janin menjadi terhambat, akibatnya melahirkan bayi BBLR (Supariasa et al. 2002). Status gizi kurang cenderung dikaitkan dengan tingkat ekonomi keluarga, tingkat ekonomi yang rendah merupakan salah satu faktor yang menyebabkan menurunnya daya beli terhadap pangan untuk memenuhi kebutuhan sehingga mempengaruhi kualitas dan kuantitas makanan yang dikonsumsi seluruh anggota keluarga. Apabila hal tersebut terus berlangsung, maka status gizi keluarga, khususnya ibu hamil akan memburuk (Proverawati \& Asfuah 2009). Penelitian ini sejalan dengan penelitian di Kota Singkawang yang menunjukkan adanya hubungan yang signifikan antara IMT dengan kejadian BBLR dengan $\mathrm{OR}=5,4$ dan IK 95\%:1,07-27,29 $(\mathrm{p}=0,03)$. Hal ini menunjukkan bahwa subjek dengan status gizi tidak normal, yaitu kurang atau lebih mempunyai risiko 5,4 kali lebih besar untuk melahirkan BBLR (Trihardani 2011). Selain itu penelitian yang dilakukan di RSUD Pringsewu Lampung juga menunjukkan adanya hubungan antara IMT ibu $<18,5 \mathrm{~kg} / \mathrm{m}^{2}$ dengan kejadian BBLR (Yusari 2014), serta penelitian yang dilakukan di Yogyakarta yang menunjukkan adanya hubungan antara IMT dengan berat lahir bayi (Nurhayati 2016).

Tabel 2 menunjukkan bahwa proporsi ibu hamil dengan BB kurang pada kelompok kasus $(83,3 \%)$ lebih tinggi dari pada kelompok kontrol (38,3\%). Hasil uji Chi-square menunjukkan bahwa ada hubungan $(\mathrm{p}<0,05)$ antara kenaikan berat badan ibu selama kehamilan dengan kejadian BBLR. BB kurang merupakan faktor risiko kejadian BBLR dapat dilihat dari nilai OR yaitu 8,0 dengan IK 95\%: 3,4-18,9 artinya subjek dengan BB kurang memiliki risiko terkena BBLR 8,0 kali lebih besar dibandingkan subjek dengan BB cukup .

Kenaikan berat badan dapat dipakai sebagai indeks untuk menentukan status gizi wanita hamil. Seorang ibu hamil yang tercukupi kebutuhan gizinya akan mengalami kenaikan berat badan. Penambahan berat badan yang terjadi selama kehamilan disebabkan oleh peningkatan ukuran berbagai jaringan reproduksi, adanya pertumbuhan janin, dan terbentuknya cadangan lemak dalam tubuh ibu, serta ibu hamil mengalami perubahan metabolik. Sebagian besar pertambahan berat badan selama hamil dihubungkan de- ngan uterus dan isinya, payudara, berubahnya volume darah serta cairan ekstrasel. Penambahan berat badan yang lebih kecil adalah akibat perubahan metabolik yang menyebabkan bertambahnya air dalam sel dan penumpukan lemak dan protein baru.

Lemak bawah kulit pada umumnya tertimbun dibagian perut serta bagian depan dan belakang paha terutama pada trimester pertama dan kedua. Penelitian ini sejalan dengan penelitian di Bogor, bahwa terdapat hubungan pertambahan berat badan selama kehamilan dan berat lahir bayi pada penelitian ini dengan nilai $\mathrm{OR}=7,3$ (Turhayati 2006) dan penelitian yang dilakukan di Bekasi dan Jatinegara menunjukkan terdapat hubungan antara kenaikan berat badan ibu dengan kejadian BBLR (Yongky et al. 2009), serta penelitian yang dilakukan di Kabupaten Banyumas menunjukkan ada hubungan antara kenaikan berat badan ibu selama hamil dengan kejadian BBLR (Puspitasari et al. 2011).

Tabel 2 menunjukkan status gizi subjek berdasarkan LiLA pada masing masing kelompok subjek. Proporsi yang KEK lebih besar pada kelompok kasus $(50,0 \%)$ dibandingkan pada kelompok kontrol $(15,0 \%)$. Sedangkan proporsi yang tidak KEK kelompok kasus $(50,0 \%)$, dan pada kelompok kontrol $(85,0 \%)$. Hasil uji Chi-square menunjukkan bahwa ada hubungan $(p<0,05)$ antara LiLA dengan kejadian BBLR. KEK apabila LiLA $<23,5 \mathrm{~cm}$ merupakan faktor kejadian BBLR dapat dilihat dari nilai OR yaitu 5,7 dengan IK 95\%: 2,4-13,5 artinya subjek dengan $\operatorname{LiLA}<23,5 \mathrm{~cm}$ memiliki risiko terkena BBLR 5,7 kali lebih besar dibanding yang nilai LiLA nya $\geq 23,5 \mathrm{~cm}$.

Ibu hamil dengan LiLA $<23,5 \mathrm{~cm}$ cenderung mengalami KEK, yang berarti ibu sudah mengalami keadaan kurang gizi dalam jangka waktu yang telah lama, bila ini terjadi maka kebutuhan nutrisi untuk proses tumbuh kembang janin menjadi terhambat, sehingga bayi yang dilahirkan BBLR. Kekurangan energi secara kronis ini menyebabkan ibu hamil tidak mempunyai cadangan zat gizi yang adekuat untuk menyediakan kebutuhan fisiologi kehamilan yakni perubahan hormon dan meningkatkan volume darah untuk pertumbuhan janin, sehingga suplai zat gizi pada janin pun berkurang. Hal ini mengakibatkan pertumbuhan dan perkembangan janin terhambat dan lahir dengan berat yang rendah (Hanifah 2009). Sesuai dengan penelitian yang dilakukan oleh Trihardiani (2011), ibu dengan KEK (LiLA $<23,5 \mathrm{~cm}$ ) mempunyai risiko 7,3 kali lebih besar untuk melahirkan bayi BBLR dibandingkan ibu dengan tidak KEK $(\operatorname{LiLA}=23,5 \mathrm{~cm})$. 
Tabel 3. Hasil analisis regresi logistik

\begin{tabular}{lccccc}
\hline \multicolumn{1}{c}{ Variabel } & \multirow{2}{*}{$\mathrm{r}$} & $\mathrm{P}$ & $\mathrm{OR}$ & \multicolumn{2}{c}{ IK 95\% } \\
& & & & Min & Maks \\
\hline Tingkat Kecukupan Protein (TKP) & 2,938 & 0,021 & 18,887 & 1,566 & 227,742 \\
Kenaikan BB selama hamil & 2,206 & 0,000 & 9,079 & 2,863 & 28,787 \\
Tingkat Paparan Pestisida (TPP) & 1,995 & 0,023 & 7,353 & 1,323 & 40,861 \\
LiLA saat hamil & 1,531 & 0,015 & 4,623 & 1,340 & 15,951 \\
Tingkat Kecukupan Energi (TKE) & 0,704 & 0,177 & 2,021 & 0,728 & 5,607 \\
IMT & 0,538 & 0,559 & 1,712 & 0,282 & 10,402 \\
Konstanta & $-3,031$ & 0,000 & 0,048 & & \\
\hline
\end{tabular}

Untuk melihat faktor risiko yang paling berpengaruh terhadap kejadian BBLR, maka dilakukan analisis multivariat. Variabel yang dijadikan kandidat dalam analisis multivariat yaitu variabel yang dalam analisis bivariat mempunyai nilai $\mathrm{p} \leq$ 0,25 . Hasil analisis multivariat dapat dilihat pada Tabel 3.

Analisis regresi logistik dilakukan terhadap enam variabel yaitu LiLA, IMT sebelum hamil, kenaikan BB selama hamil, tingkat kecukupan energi (TKE), tingkat kecukupan protein (TKP), tingkat paparan pestisida (TPP). Berdasarkan hasil analisis regresi logistik secara multivariat (Tabel 3) menunjukkan variabel yang paling berpengaruh terhadap kejadian BBLR adalah TKP, kenaikan BB selama hamil, TPP, dan LiLA saat hamil. Berdasarkan hasil analisis regresi logistik secara multivariat (Tabel 3), variabel yang berpengaruh terhadap kejadian BBLR adalah LiLA, kenaikan berat badan, TKE, TKP dan TPP.

\section{KESIMPULAN}

Berdasarkan hasil studi faktor risiko BBLR antara lain, TKE $<90,0 \%$ AKG ibu hamil, TKP $<90,0 \%$ AKG ibu hamil, LiLA ibu $<23,5 \mathrm{~cm}$ selama hamil, kenaikan $\mathrm{BB} \leq 10 \mathrm{~kg}$ selama hamil, dan paparan pestisida yang tinggi pada ibu hamil. Bagi ibu perlu dilakukan upaya peningkatan asupan karbohidrat, sumber protein, selain itu diperlukan upaya penyuluhan melalui kelas ibu hamil. Bagi petugas kesehatan dan penyuluh pertanian perlu adanya kerjasama dalam upaya penurunan paparan pestisida ibu hamil melalui penggunaan alat pelindung diri seperti pemakaian masker, penggunaan sarung tangan, cuci tangan sewaktu melakukan aktivitas pertanian dan pembersihan diri setelah melakukan aktivitas pertanian. Selain itu, tidak ikut serta dalam pemeliharaan bawang merah atau proses lainnya seperti penanaman, pemanenan, pembersihan dan penyemprotan.

\section{DAFTAR PUSTAKA}

Cahaya, Indra, Maria E. 2007. Faktor-faktor yang berhubungan dengan cholinesterase darah pada penyemprot pestisida Jenis malathion di Kota Medan. Jurnal Info Kesehatan Masyarakat 11(1):24-32.

Departemen Kesehatan (Depkes RI). 2009. Direktorat Gizi Masyarakat Depkes RI. Angka Kematian Bayi (AKB). Jakarta; Dinas Kesehatan Republik Indonesia:5-6.

Dinas Kesehatan Provinsi Jawa Tengah. 2014. Profil Kesehatan Dinas Kabupaten Brebes. Brebes: Dinas Kesehatan Kabupaten Brebes (1):11-14.

Dinas Kesehatan Provinsi Jawa Tengah. 2013. Buku Saku Kesehatan. Semarang: Dinas Kesehatan Provinsi Jawa Tengah:222-225.

Fikawati S, Wahyuni D, Syafiq A. 2012. Status gizi ibu hamil dan berat lahir bayi pada kelompok vegetarian. Makara Kesehatan 16 (1):29-35.

Fusani D, Seta DF, Fulgheri and Farabollini F. 2007. Altered reproductive success in rat pairs after environmental-like exposure to xenoestrogen. Proceedings Biological sciences / The Royal Society 274(1618): 1631-1636.

Hanifah L. 2009. Hubungan antara status gizi ibu hamil dengan berat badan bayi lahir studi kasus di RB Pokasi [Thesis]. Surakarta: Fakultas Kedokteran Universitas Sebelas Maret.

Hardinsyah. 2004. Angka Kecukupan Energi, Protein, Lemak dan Serat Makanan. Prosiding Widyakarya Pangan dan Gizi VIII; 2004 Mei 17-19; Jakarta:323-327.

Kusuma S, Kartasurya MI, Kartini A. 2015. Status gizi pada ibu hamil sebagai faktor risiko kejadian berat bayi lahir rendah (studi di kecamatan Bandung Kabupaten Tulungagung), Jurnal Kesehatan Masyarakat (eJournal) (3):1. (ISSN: 2356-3346) http:// ejournal-s1.undip.ac.id/index.php/jkm.

Manuaba IBG, IAM Chandranita, IBG M Fajar. 2007. Pengantar Kuliah Obstetri. Jakarta: Buku Kedokteran EGC.

Moore Mc. 2006. Buku Pedoman Terapi Diet Dan Nutrisi. Edisi 2. Jakarta; Hipokrates (2):25-27. 
Muwakidah dan Zulaekah S. 2004. Hubungan kenaikan berat badan ibu hamil dengan berat bayi lahir di RSUD DR. Moewardi Surakarta. Jurnal Penelitian Sains \& Teknologi. 5(1):11-20.

Nahar S, Taylor MCGN \& Begum HA.2007. Maternal Antropometry as a predictor of birth weight, public health Nutr (107):965970.

Nurhayati E. 2016. Indeks massa tubuh (IMT) Pra hamil dan kenaikan berat badan ibu selama hamil berhubungan dengan berat badan bayi lahir. Jurnal Ners dan Kebidanan Indonesia 4(1):1-5.

Paath EF, dkk. 2004. Gizi Dalam Kesehatan Reproduksi. Jakarta; EGC.

Proverawati A dan Asfuah S.2009. Gizi Untuk Kebidanan. Yogyakarta: Mulia Medika 4 (2):37-50.

Puspitasari C, Anasari T, Fajarsari D. 2011. Hubungan antara kenaikan berat badan selama kehamilan dengan berat bayi baru lahir di wilayah kerja puskesmas Rawalo Kabupaten Banyumas. Jurnal Ilmiah Kebidanan 2(1):54-67.

Rahmaniar A, Nurpudji A, Taslim, Burhanuddin Bahar. 2011. Faktor faktor yang berhubungan dengan kekurangan energi kronis pada ibu hamil di tampa padang, Kabupaten Mamuju, Sulawesi Barat 3(1):1-14.

Rahmawati, Nur JRA. 2010. Pengaruh faktor maternal terhadap kejadian Bayi berat badan lahir rendah di rumah sakit umum daerah Ajjatpannge Watan Soppeng Kabupaten Soppeng. Jurnal Medika Kebidanan Poltekkes Makasar (2).

Rosha B, Putri IS, Amaliah N. 2012. Analisis determinan berat bayi lahir rendah (BBLR) pada anak usia 0-59 bulan di Nusa Tenggara Timur, Kalimantan Tengah dan Papua. Jurnal Ekologi Kesehatan 11(2):123-135.

Rukmana SC, Kartasurya MI. 2014. Hubungan asupan gizi dan status gizi ibu hamil trimester III dengan berat badan lahir bayi di wilayah kerja puskesmas Suruh Kabupaten Semarang. Jurnal of Nutrition Collage 3(1):192-199.

Sari NK, Budiyono, Hanani Y. 2013. Hubungan riwayat pajanan pestisida pada ibu jamil dengan kejadian berat badan lahir rendah (BBLR) di wilayah kerja puskesmas Wanasari Kabupaten Brebes. Jurnal Kesehatan Masyarakat 12(1):26-33.

Setyobudi B, Setiani O, Endah WN. 2013. Hubungan paparan pestisida pada masa kehamilan dengan kejadian berat badan bayi lahir rendah (BBLR) di Kecamatan Ngablak Kabupaten Magelang. Jurnal Kesehatan Lingkungan Indonesia 12(1):2633.

Sigalingging G. 2009. Pengaruh tingkat pengetahuan ibu hamil tentang gizi pada ibu hamil di klinik bersalin Sam Medan.Medan. 2009. Diakses dari http://uda.ac.id/jurnal/ files/Ganda\%20Sigalingging2.pdf.

Supariasa IMN, B Bachyar B, Ibnu F.2002. Penilaian Status Gizi. Jakarta: EGC.

Survei Demografi dan Kesehatan Indonesia. 2012. Laporan Pendahuluan, Badan Pusat Statistik, Badan Kependudukan dan Keluarga Berencana Nasional, dan Kementerian Kesehatan Republik Indonesia (1):225227.

Torrance B, Mc Guire A, Lewnczuk. Overweight, 2007. Physical activity and high blood pressure in children: a review of the literature. Vascular Health and Risk Management 3(1):139-149.

Trihardiani I. 2011. Faktor risiko kejadian berat badan lahir rendah di wilayah kerja Puskesmas Singkawang Timurdan Utara Kota Singkawan [Thesis]. Program Studi Ilmu Gizi Fakultas Kedokteran Universitas Diponegoro.

Turhayati ER. 2006. Hubungan pertambahan berat badan selama kehamilan dengan berat lahir bayi di Sukaraja Bogor Tahun 20012003. Kesmas Jurnal Kesehatan Masyarakat Nasional 7(1):1-3.

Yongky, Hardinsyah, Gulardi, Marhamah. 2009. Status gizi awal kehamilan dan pertambahan berat badan ibu hamil kaitannya dengan BBLR. Jurnal Pangan dan Gizi 4(1):8-12.

Yusari A. 2014. Indeks massa tubuh (IMT) pada kejadian BBLR di RSUD Pringsewu Lampung. Jurnal Keperawatan 10(1):70-74. 